\title{
BƯớC ĐẦU ĐÁNH GIÁ KẾT QUẢ TRIỂN KHAI KỸ THUẬT MỔ TIM HỞ TẠI BỆH VIỆN ĐA KHOA TRUNG ƯƠNG CẦN THƠ
}

\author{
Lâm Việt Triều*, Hà Bủu Kiếm*, Phạm Thanh Phong*, Trần Quyết Tiến**, \\ Nguyễn Thái An**, Phạm Thị Lệ Xuân***, Trần Thị Diê̂m Quỳnh***
}

\section{I. ĐẶT VẤN ĐỀ}

Bệnh lý tim mạch là vấn đề lớn của xã hội và hiện đang có xu hướng gia tăng. Việc phát hiện và điều trị sớm là rất cần thiết nhằm đạt hiệu quả điều trị tối ưu. Tại Việt Nam do hoàn cảnh địa lý; giao thông; phân bố nguồn nhân lực y tế chưa đồng đều; các trung tâm phẫu thuật tim đa phần ở các thành phố lớn nên việc tiếp cận điều trị gặp nhiều khó khăn, tốn kém. Do đó việc triển khai kỹ thuật mổ tim hở tại bệnh viện địa phương là thật sự cần thiết giúp mang lại hiệu quả kinh tế; xã hội; góp phần nâng cao năng lực chuyên môn y tế tuyến tỉnh và giải quyết quá tải bệnh viện tuyến trên và trung ương.

Khu vực đồng bằng sông Cửu Long với đặc thù dân cư đông đúc; điều kiện địa lý nhiều sông ngòi; hải đảo và điều kiện giao thông chưa thuận lợi. Số lượng các cơ sở y tế thực hiện được các điều trị kỹ thuật cao còn ít.

Nhằm đáp ứng nhu cầu thực tế này: Bệnh Viện Đa Khoa Trung Ương Cần Thơ với vai trò là bệnh viện tuyến cuối Bộ Y Tế ở khu vực đồng bằng sông Cửu Long đã đầu tư triển khai kỹ thuật mổ tim hở từ đầu năm 2015 với sự hỗ trợ chuyên môn từ Bệnh Viện Chợ Rẫy TP.HCM.

\section{II. ĐỐI TƯợNG VÀ PHƯƠNG PHÁP NGHIÊN CÚU.}

\section{1. Đối Tượng Nghiên Cứu:}

Những bệnh nhân được phẫu thuật tim tại Bệnh Viện Đa Khoa Trung U’ơng Cần Thơ.

\subsection{Phương Pháp Nghiên Cứu:}

Hồi cứu tổng kết số lượng bệnh nhân đã được phẫu thuật tim tại Bệnh Viện Đa Khoa Trung Ương Cần Thơ trong thời gian 03 năm( từ 03/2015 đến 03/2018). Đánh giá kết quả qua số lượng bệnh nhân; loại bệnh được phẫu thuật; kết quả phẫu thuật; thời gian theo dõi.

\section{KẾT QUẢ:}

Từ tháng 03/2015 đến tháng 03/2018:

Số lượng bệnh nhân phẫu thuật: 124 trường hợp.

\subsection{Tuổi, Giới tính, Cân nặng:}

- Tuổi trung bình: 38.6. nhỏ nhất: 18 tuổi, lớn nhất: 81 tuổi

- Giới tính: Nam: 42; Nữ: 82.

- Cân nặng: nhỏ nhất: 35kg, nặng nhất: 77 kg.

\subsection{Phân loại bệnh:}

\begin{tabular}{|l|c|c|}
\hline \multicolumn{1}{|c|}{ PHÂN LOẠI BỆNH } & $\begin{array}{c}\text { Số } \\
\text { lượng }\end{array}$ & Tỷ lệ \\
\hline Bệnh tim bẩm sinh & $\mathbf{1 8}$ & $14,51 \%$ \\
\hline Tứ chứng Fallot & 01 & $0,81 \%$ \\
\hline Thông liên nhĩ & 12 & $9,67 \%$ \\
\hline Thông liên thất & 04 & $3,22 \%$ \\
\hline Hẹp động mạch phối & 01 & $0,81 \%$ \\
\hline Bệnh tim mắc phải & $\mathbf{1 0 6}$ & $85,49 \%$ \\
\hline Bệnh van động mạch chủ đơn thuần & 08 & $6,44 \%$ \\
\hline Bệnh van 2 lá đơn thuần & 75 & $60,48 \%$ \\
\hline Bệnh van động mạch chủ và van 2 lá. & 10 & $8,06 \%$ \\
\hline U nhầy nhĩ trái & 08 & $6,44 \%$ \\
\hline Bệnh mạch vành đơn thuần & 01 & $0,81 \%$ \\
\hline Bệnh mạch vành và van 2 lá. & 02 & $1,62 \%$ \\
\hline Phình động mạch chủ ngực đoạn lên & 02 & $1,62 \%$ \\
\hline \multicolumn{1}{|c|}{ TỐNG SỐ } & $\mathbf{1 2 4}$ & $100 \%$ \\
\hline
\end{tabular}

* Khoa Phẫu thuật tim - Trung tâm tim mạch Bệnh Viện Đa Khoa Trung Uơng Cần Tho

** Khoa Hồi sức - Phẫu thuật tim Bệnh Viện Chợ Rẫy. *** Khoa Phẫu thuật-Gây mê hồi sức Bệnh Viện Chợ Rẫy Nguoòi chịu trách nhiệm khoa học: TS. Pham Minh Änh Ngày nhận bài: 01/05/2018 - Ngày Cho Phép Đăng: 20/05/2018

Phản Biện Khoa học: PGS.TS. Đặng Ngọc Hùng GS.TS. Lê Ngọc Thành 


\subsection{Thời gian nằm ở phòng hồi sức:}

Trung bình là: 3,2 ngày. Ít nhất: 01 ngày; nhiều nhất: 23 ngày.

\subsection{Thò̀i gian nằm viện:}

Trung bình: 14 ngày. Ít nhất: 05 ngày; nhiều nhất: 33 ngày.

\subsection{Kết quả sớm:}

Biến chứng trong mổ: Không.

Biến chứng sau mồ:

- Chảy máu, mổ lại cầm máu: 01( $0,81 \%)$.

- Tràn khí màng phổi: 03( 2,42\%).

- Tràn dịch màng phổi: 05( 4,03\% ).

- Tràn dịch màng ngoài tim: $03(2,42 \%)$.

- Rối loạn nhịp tạm thời: 04( 3,22\%).

- Rối loạn nhịp vĩnh viễn: 01( 0,81\%).

- Nhiễm trùng vết mổ: $01(0,81 \%)$.

- Tử vong trong thời gian nằm viện:

$$
01(0,81 \%) \text {. }
$$

Kết quả sớm: 123/ 124 (99,19\%).

\subsection{Thò̀i gian theo dõi:}

- Dài nhất: 36 tháng.

- Ngắn nhất: 01 tháng.

\section{BÀN LUẬN:}

Trong thời gian đầu triển khai kỹ thuật phẫu thuật tim tại Bệnh Viện Đa Khoa Trung Ương Cần Thơ. Chúng tôi chọn lựa những bệnh tim bẩm sinh người lớn đơn giản; bệnh van tim hậu thấp chưa có biến chứng, bệnh lý không phức tạp, cân nặng ít nhất là $35 \mathrm{~kg}$. Tuổi nhỏ nhất phẫu thuật là 18 tuổi, chẩn đoán: Hẹp khít van hai lá. Tuổi lớn nhất là 81 tuổi, chẩn đoán: U nhày nhĩ Trái. Bệnh thường hay gặp: Thông liên nhĩ ( $9,67 \%$ ) và bệnh lý van hai lá hậu thấp( $60.48 \%$ ).

Trong 124 trường hợp: Có 09 trường hợp chúng tôi phẫu thuật cấp cứu. 01 bệnh nhân nữ, 58 tuổi, chẩn đoán: Hẹp khít van hai lá; rung nhĩ; tăng áp động mạch phổi nặng; phù phổi cấp; xử trí: Thay van hai lá sinh học; Cox - Maze procedure; sửa van ba lá bằng vòng mềm St.Jude Tailor. 08 trường hợp chẩn đoán u nhầy nhĩ Trái biến chứng lấp van hai lá. Cả 09 trường hợp này đều có diễn tiến hậu phẫu ổn định và xuất viện.

Có 01 trường hợp bệnh nhân tử vong chu phẫu trong thời gian nằm viện do nguyên nhân rối loạn nhịp tim phát hiện muộn.

Nhìn chung, qua thời gian 03 năm triển khai kỹ thuật phẫu thuật tim chúng tôi đạt được tỷ lệ thành công đáng khích lệ: 99,19\%. Tuy nhiên, chúng tôi cũng gặp một số biến chứng, thường gặp nhất là loạn nhịp tim tạm thời ( $3,22 \%)$ ở những bệnh nhân bị bệnh lý van 2 lá. Đặc biệt chúng tôi có 01 trường hợp $(0,81 \%)$ rối loạn nhịp vĩnh viễn sau phẫu thuật Maze điều trị rung nhĩ bằng sóng cao tần: Bệnh nhân này phải cấy máy tạo nhịp vĩnh viễn. Có 01 trường hợp phải mổ lại vì chảy máu mặt sau xương ức. Trong 03 trường hợp tràn dịch màng ngoài tim: 01 dẫn lưu khoang màng tim; 02 chọc hút dịch dưới hướng dẫn của siêu âm. Trong 08 trường hợp tràn khí; tràn dịch màng phổi: 07 đáp ứng tốt với tập vật lý trị liệu hô hấp; 01 dẫn lưu màng phổi. Những biến chứng này đều được chúng tôi xử lý kịp thời và cho kết quả tốt.

Thời gian nằm hồi sức và thời gian nằm viện trong nghiên cứu của chúng tôi tương đối dài do trong thời gian đầu chúng tôi cẩn thận và giữ bệnh nhân ở phòng hồi sức để thuận tiện theo dõi. Thực tế sau này thời gian nằm hồi sức và thời gian nằm viện đã được rút ngắn tương đương các trung tâm lớn.

Kế hoạch trong thời gian tới, chúng tôi sẽ phẫu thuật cho những trường hợp bệnh đa dạng và phức tạp hơn; cũng như triển khai các kỹ thuật chuyên sâu trong phẫu thuật tim: Phẫu thuật quai động mạch chủ; phẫu thuật tim xâm lấn tối thiểu( MICS )...

\section{KẾT LUẬN}

Việc triển khai kỹ thuật mổ tim hở tại Bệnh Viện Đa Khoa Trung U’ơng Cần Thơ đạt kết quả 
khả quan và cần tiếp tục phát triển các kỹ thuật chuyên sâu trong phẫu thuật tim.

Qua đánh giá kết quả triển khai kỹ thuật mổ tim hở tại Bệnh Viện Đa Khoa Trung Ương Cần Thơ cho thấy mổ tim hở hoàn toàn có khả năng triển khai tại bệnh viện địa phương với kết quả tốt và cần phát huy, nhân rộng mô hình này.

\section{TÀI LIẸU THAM KHẢO}

1. Nguyễn Hữu Ước, Đặng Hanh Đệ (2002): Điều trị ngoại khoa trong bệnh van tim do thấp. Thấp tim và bệnh tim do thấp. Nhà xuất bản Y Học 2002: 288.

2. Trần Quyết Tiến, Trần Minh Trung( 2011 ): Đánh giá kết quả điều trị ngoại khoa bệnh hẹp khít van hai lá có tăng áp động mạch phổi nặng. Tạp chí Y Học Thành Phố Hồ Chí Minh: $475-479$.

3. Nguyễn Văn Phan( 2008 ): Điều trị phẫu thuật bệnh van tim. Điều trị học ngoại khoa lồng ngực: $248-264$.

4. Phan Kim Phương( 2008 ): Điều trị các bệnh tim bẩm sinh thường gặp. Điều trị học ngoại khoa lồng ngực: $265-282$.

5. Phạm Nguyễn Vinh( 2006 ): Hẹp van 2 lá. Bệnh học tim mạch, tập 2: 15 - 26.

6. Đào Hữu Trung( 2006 ): Thông liên thất. Bệnh học tim mạch, tập 2: 389 - 397.

7. Lâm Việt Triều, Trần Quyết Tiến( 2016 ): Bước đầu đánh giá kết quả chuyển giao kỹ thuật mổ tim hở của bệnh viện Chợ Rẫy tại bệnh viện tỉnh Kiên Giang. Tạp chí Y Học Việt Nam: $116-119$.

8. Robert M. Bojar( 2005 ): Early postoperative care. Manual of perioperative care in aldult cardiac surgery: $237-258$.

9. Elliot M. Antman, MD( 2007 ): Surgery for valvular heart disease. Cardiovascular therapeutics: $815-841$.
10. Kirlin/ Barratt - Boyes( 2003 ): Ventricular septal defect. Cardiac surgery, third edition: $850-909$.

11. Kirlin/ Barratt - Boyes( 2003 ): Patent ductus arteriosus. Cardiac surgery, third edition: $928-945$.

12. Ashish A.Bartakke, Giles J.Peek( 2009

): Extracorporeal membrane oxygenation.

Cardiopulmonary bypass ; 14: 176.

13. Andrew Snell, Barbora Prizkova( 2009 ): Organ damage during cardiopulmonary by pass. Cardiopulmonary bypass ; 11: 140.

14. Alejandro Aris, MD, $\operatorname{PhD}(1996$ ): One Hundred Years of Cardiac Surgery. Ann Thorac Surg 1996; 62: 636.

15. Mitral valve replacement. Mastery of Cardiothoracic Surgery second edition 2007. Chapter 42: 378-390.

16. Mitral valve disease with or without triscupid valve disease. Cardiac surgery third edition 2003. Volume 1, chapter 11: $483-553$.

17. Mitral valve disease. Kirklin \& BarrattBoyes Cardiac Surgery 3rd. Part III: 525 -542.

18. Anatomy, dimensions, and terminology( 2003 ). Cardiac surgery third edition 2003.

Volume 1, chapter 01: 03-65.

19. Adrew C. Cook, Benson R Wilcox and Robert H Anderson( 2010 ): Surgical anatomy of the heart. Surgery of the chest $8^{\text {th }}$. Chapter 46 : $735-752$.

20. A. Constantine, Gerald D. Buckberg( 2009 ): Myocardio protection and cardioplegia. Cardiopulmonary bypass; 7: 80.

21. Rick A. Nishimura( 2014 ): Guideline for the management of patients with valvular heart disease ; 2014 AHA/ACC: 67 :80. 